\title{
PUBLIC LONG-TERM CARE INSURANCE AND THE HOUSING AND LIVING ARRANGEMENTS OF THE ELDERLY: EVIDENCE FROM MEDICARE HOME HEALTH BENEFITS
}

\author{
Gary V. Engelhardt and Nadia Greenhalgh-Stanley
}

CRR WP 2008-15

Released: December 2008

Date Submitted: October 2008
Center for Retirement Research at Boston College
Hovey House
140 Commonwealth Avenue
Chestnut Hill, MA 02467

Tel: 617-552-1762 Fax: 617-552-0191

The research reported herein was pursuant to a grant from the U.S. Social Security Administration (SSA) funded as part of the Retirement Research Consortium (RRC). The findings and conclusions expressed are solely those of the authors and do not represent the views of SSA, any agency of the Federal Government, the RRC, or Boston College.

(C) 2008, by Gary V. Engelhardt and Nadia Greenhalgh-Stanley. All rights reserved. Short sections of text, not to exceed two paragraphs, may be quoted without explicit permission provided that full credit, including $(\subset)$ notice, is given to the source. 


\title{
About the Center for Retirement Research
}

The Center for Retirement Research at Boston College, part of a consortium that includes parallel centers at the University of Michigan and the National Bureau of Economic Research, was established in 1998 through a grant from the Social Security

Administration. The Center's mission is to produce first-class research and forge a strong link between the academic community and decision makers in the public and private sectors around an issue of critical importance to the nation's future. To achieve this mission, the Center sponsors a wide variety of research projects, transmits new findings to a broad audience, trains new scholars, and broadens access to valuable data sources.

\author{
Center for Retirement Research at Boston College \\ Hovey House \\ 140 Commonwealth Avenue \\ Chestnut Hill, MA 02467 \\ phone: 617-552-1762 fax: 617-552-0191 \\ e-mail: crr@bc.edu \\ www.bc.edu/crr
}

Affiliated Institutions:

The Brookings Institution

Massachusetts Institute of Technology

Syracuse University

Urban Institute 


\begin{abstract}
We provide empirical evidence on the extent to which long-term care insurance affects the housing and living arrangements of the elderly by examining plausibly exogenous changes in the supply of long-term care insurance through the Medicare program that occurred in the late 1990s. Prior to 1997, Medicare reimbursed home health care agencies on a retrospective-cost basis. Then, starting in October, 1997, as a result of the Balanced Budget Act of 1997 (BBA97), Medicare switched to a system of prospective payments for home health care, which induced state-by-calendar-year variation in the supply of this type of public long-term care insurance. We exploit this variation to econometrically identify the impact on the housing and living arrangements of the elderly, using CPS data from 1995-2000 (before and after the law change). Our estimates indicate that living arrangements are quite responsive to home health care benefits. The estimated elasticity of shared living to benefits is -0.7 over all elderly and -1 for widowed elderly. However, these benefits have little impact on household headship among the elderly. This suggests that the bulk of the shared-living response occurred through co-residents living in elderly households. There is some weak evidence that increases in benefits raised elderly homeownership.
\end{abstract}




\section{Introduction}

As the American population ages and end-of-life medical costs rise, there is growing interest in insurance markets for long-term care. Because the private market for such insurance is small, and the publicly provided insurance in the form of Medicaid only covers older individuals who are sufficiently poor, particular attention has been placed on increasing coverage through tax incentives and the expansion of existing programs.

Housing economists should be keenly interested in long-term care insurance for at least four reasons. First, unlike many other goods, there is a close link between functional status, health, and housing decisions, especially among older individuals (Engelhardt, 2005). In particular, housing and health are likely complements in consumption. Given the great desire of the elderly to live independently and age in place, long-term care insurance, which transfers resources from healthy to sick states of the world, may allow older individuals to stay in their homes longer, thus raising elderly homeownership rates. Second, such insurance provides a funding source for the purchase of market-based services that may substitute for home-produced, informal care. This may attenuate the incidence of shared living arrangements and influence household-formation decisions among the elderly, key determinants of housing demand. Third, because housing wealth can be used to self-insure against long-term care expenditures, there are direct linkages between motives for and the timing of housing wealth decumulation and the demand for long-term care insurance, as well as other actuarial products, such as private annuities and reverse mortgages (Davidoff, 2008a, 2008b). Finally, housing wealth receives favorable treatment in means-tested social insurance programs targeted to the aged, particularly Medicaid, the primary insurer against large long-term care expenses. Therefore, the structure of public long-term care insurance may influence the relative demand for housing assets.

Whereas there is a voluminous literature in urban and public economics on housing decisions, there has been remarkably little recent housing research on the elderly in general, and even less on the impact of long-term care on elderly housing decisions in particular. ${ }^{1}$ The small

\footnotetext{
${ }^{1}$ In a recent literature survey by Dietz and Haurin (2003), only one-and-a-half out of fifty pages and 11 out of 251 articles surveyed were devoted to elderly housing, and there were no studies devoted to the impact of long-term care insurance on housing decisions. There is, however, a long literature in health economics and health services research on long-term care (e.g., Norton, 2000).
} 
existing empirical housing literature on the elderly has focused primarily on the extent to which the elderly decumulate housing equity as they age (e.g., Merill, 1984; Feinstein and McFadden, 1989; Reschovsky, 1990; Megbolugbe, Sa-Aadu, and Shilling, 1997, 1999; Venti and Wise, 1989, 1990, 2000, 2001) and analyses of the potential market for reverse mortgages (Mayer and Simons, 1994; Kutty, 1998; Venti and Wise, 1991; among others). An important exception is the recent work of Davidoff (2008a, 2008b), who has begun to explore the interplay between housing wealth and the demand for long-term care insurance and annuities.

The primary aim of the current paper is to provide empirical evidence on the first two topics above: the extent to which long-term care insurance affects the housing and living arrangements of the elderly. ${ }^{2}$ Because the decisions to purchase private long-term care insurance and housing are almost surely jointly determined, we do not focus on the market for private insurance. Instead, we attempt to identify the impact on housing and living arrangements by examining plausibly exogenous changes in the supply of public long-term care insurance through the Medicare program that occurred in the late 1990's. Specifically, Medicare-the primary insurer for acute care among those 65 and older-reimburses expenditures for home health care, which is long-term care delivered in a home setting. Unlike Medicaid, Medicare eligibility is not means-tested.

Prior to 1997, Medicare reimbursed home health care agencies on a retrospective-cost basis. In 1996, for example, 15\% of 75-84 year olds and 26\% of those 85 and older received home health care benefits, and expenditure represented 10\% of total Medicare program payments. Then, starting in October, 1997, as a result of the Balanced Budget Act of 1997 (BBA97), Medicare switched to a system of prospective payments for home health care. This resulted in a 30\% decline in Medicare expenditures on home health care and a substantial decline in home health care use. Importantly, up through 2000, the new prospective payment system was implemented in a way that effectively differed across states, so that the 1997 law induced state-by-calendar-year variation in the supply of this type of public long-term care insurance. We exploit this variation to econometrically identify the impact on the housing and living arrangements of the elderly, using data on over 57,000 elderly families from 1995-2000 (before and after the law change) from the March Current Population Surveys (CPS).

\footnotetext{
${ }^{2}$ We discuss the implications for our findings for the other two topics in the conclusion.
} 
There are three primary findings. First, our estimates indicate that increases in home health care benefits decrease the incidence of shared living arrangements among the elderly: the elasticity of shared living to benefits is -0.7 over all elderly and -1 for widowed elderly. Second, there was little impact on household headship among the elderly. This suggests that the bulk of the shared-living response occurred through co-residents living in elderly households (and not the reverse). Finally, there is some, but weak, evidence that increases in benefits raised elderly homeownership, with an elasticity of 0.2 for all elderly. Overall, the results suggest that future expansions in public benefits have the potential to alter elderly housing and living arrangements significantly.

The paper is organized as follows. Section II gives background on long-term care, Medicare home health benefits, and the Balanced Budget Act of 1997. Section III discusses findings from the previous literature. Section IV describes the CPS and the construction of the analysis dataset. It draws on some of the methods and exposition developed in a companion set of papers on the impact of Social Security on the elderly by Engelhardt (2008), Engelhardt, Gruber, and Perry (2005) and Engelhardt and Gruber (2005, 2006). Section V charts the timeseries evolution of elderly living arrangements, headship, and homeownership during the period of study. Sections VI and VII discuss the regression framework and estimation results, respectively. The paper ends with a summary of findings, a discussion of caveats, and directions for future research.

\section{Background}

Broadly speaking, long-term care can be defined as the receipt of assistance or help with at least one Activity of Daily Living (ADL) — bathing, eating, dressing, walking across a room, and getting in and out of bed—or one Instrumental Activity of Daily Living (IADL) — using a telephone, taking medication, handling money, shopping, and preparing meals. Under this definition, of 34.5 million individuals 65 and older, there were 5.5 million receiving long-term care in 1999, of which only 30\% were institutionalized (United States Congress, Committee on Ways and Means, 2004). In addition to informal care provided by family and friends, there are three main classes of formal providers of long-term care for the elderly: nursing homes, assisted 
living facilities, and home health care agencies. In 2001, just after our sample period, long-term care spending represented $12.2 \%$ of all U.S. health care spending, and was financed $48.3 \%$ by Medicaid, which is public health insurance for the poor, $14.2 \%$ by Medicare, which is public health insurance for the aged, $22 \%$ by out-of-pocket payments, $9.6 \%$ by private insurance, and $5.9 \%$ through other means (United States Congress, Committee on Ways and Means, 2004).

While Medicaid traditionally has always been the primary source of funding for such expenditures, Medicare experienced rapid growth in the 1990's in expenditures on long-term care administered in the form of home health care benefits, which cover care by a certified home health care agency in the residence of a home-bound individual if intermittent or part-time skilled nursing or other therapy is necessary. Importantly, although a physician-approved treatment plan is required, there are no limitations on the duration of these benefits, and no deductibles or co-payments.

Figure 1 plots real annual Medicare home health care expenditures (in \$2001) for 19822000 taken from various issues of the Health Care Financing Administration's Medicare and Medicaid Statistical Supplement. After remaining relatively small in the early 1980's, home health expenditures began to rise rapidly after coverage was expanded in 1988, from about $\$ 2$ billion to $\$ 18$ billion in 1997. During this period, Medicare reimbursed home health care services on a retrospective-cost basis, essentially at actual cost up to a national-average cost cap. In an effort to control rapidly rising costs, the Balanced Budget Act of 1997 (BBA97) mandated that Medicare move from a retrospective to a prospective payment system (PPS) for home health care agencies by 2000.

From 1997-2000, Medicare instituted an interim prospective payment system (IPS), in which each agency's reimbursement was capped annually, based on a weighted average of the agency's 1994 average cost (75\% weight) and the 1994 Census division’s average cost (25\% weight). The IPS had the effect of changing reimbursement rates differentially across time and location according to the (pre-determined) cost structure in 1994. As illustrated in Figure 1, the introduction of the IPS substantially reduced Medicare home health care total spending.

In addition, Figure 2 plots home health care spending per user, participation, and visits per user. In the figure, the series for participation and visits are shown in index form, where the base year (1982) is scaled to equal 100, and the two series are re-scaled so that they fit on the 
same axes. The text box in the top left gives the base-year values to convert the index to levels. Expenditures per user, participation, and visits per user track each other very closely. Therefore, by a variety of metrics, the introduction of the IPS substantially reduced Medicare home health care activity.

\section{Existing Studies}

There are four strands in the existing literature that are particularly relevant. The first is a set of recent studies that have examined the impact of Medicaid, the largest source of long-term care insurance, on the demand for private long-term insurance (Brown and Finkelstein, 2004; Brown, Coe, and Finkelstein, 2006), housing wealth (Coe, 2007), and homeownership (Greenhalgh-Stanley, 2008) using data from the 1990's drawn from the Health and Retirement Study. In general, they have concluded that the structure of Medicaid not only crowds out purchases of private long-term care insurance, but also affects end-of-life housing decisions. With the exception of Greenhalgh-Stanley (2008), those studies have relied only on cross-state variation in Medicaid eligibility rules, as there has been essentially very little recent time-series policy variation that has differed across states.

The second is a set of studies on the impact of other social insurance programs on the housing and living arrangements of the elderly. These include work investigating the impact on living arrangements of Social Security by Michael, Fuchs, and Scott (1976), McGarry and Schoeni 2000, Engelhardt, Gruber, and Perry (2005), and Costa (1999) on state Old Age Assistance programs. These studies have concluded that elderly living arrangements are quite responsive to Social Security benefits. In particular, Engelhardt, Gruber, and Perry (2005) used year-of-birth variation in benefits from the Social Security "notch" and estimated elasticities of shared living with respect to benefits of -0.4 for all elderly and -1.3 for widowed elderly. Engelhardt (2008) examined the effects of Social Security on homeownership and headship decisions. He estimated elasticities of homeownership with respect to benefits of 0.5 for all elderly and 0.7 for widowed elderly, and elasticities of headship with respect to benefits of 0.1 for all elderly and 0.3 for widowed elderly. In combination, these studies suggest that elderly housing and living arrangements are quite responsive to social insurance benefits. 
A third strand has focused more narrowly on the impact of public home care subsidies on informal care and living arrangements. The most ambitious of these is Hoerger, Picone, and Sloan (1996) who estimated a structural multinomial probit model of the impact of public subsidies and informal care on elderly living arrangements (nursing home, intergenerational, and independent living) using data from the 1982, 1984, and 1989 National Long-Term Care Surveys. Qualitatively, they found that increases in Supplemental Security Income (SSI) and the Medicaid home health care subsidy lowered the likelihood of shared living. However, quantitatively, our calculations based on their estimated marginal effects and sample means suggest very low elasticities of shared living with respect to these policy variables. Another important study is Pezzin, Kemper, and Reschovsky (1996), who presented experimental evidence from the early 1980's on the impact on living arrangements from randomly assigned home care subsidies from the Channeling Experiment. Again, qualitatively, they found that increases in care subsidies lowered the likelihood of shared living, but the quantitative effects were quite small.

The final strand in the literature consists of specific studies on the impact of the changes to Medicare home health care from BBA97. While there are a number of studies in health services research on specific health-related aspects of the reform, there are two economic studies that are most closely related to ours. The first is McKnight (2006), who studied the impact of BBA97 on Medicare home health care utilization, expenditure, and patient health, using individual data from the Medicare Current Beneficiary Survey (MCBS). She exploited the fact that under IPS the weighted-average reimbursement cap at the agency level generated state-level variation in reimbursements and utilization as well. In particular, states with 1994 Medicare home health care expenditures below the Census-division average (which, of course, had agencies with below-average costs) saw their utilization rise after (relative to before) BBA97, compared to states with above-Census-division-average costs, where utilization was measured by the number of home visits per home health user. Using this variation in visits per user in a difference-in-difference regression framework, she found that while private out-of-pocket medical expenditures rose 22 cents for each dollar decline in Medicare expenditures, there was no discernable impact on elderly health. 
One potential explanation for this is that in response to the decline in the generosity of Medicare reimbursements for home health care, families substituted informal care for the purchase of market-based services from home health care agencies. ${ }^{3}$ In our analysis below, we focus on a complement to informal care, shared living arrangements. After we commenced our analysis and received funding for this project from the Social Security Administration, we were made aware of an unpublished study by Orsini (2007), who used methods similar to McKnight's and found a fairly substantial impact on shared living from the law change.

Orsini's study shares a number of features with our approach. Like ours, it examines the impact of the change in Medicare home health care benefits from BBA97 on living arrangements and even uses data from the CPS. That said, our analysis differs from hers in three ways. First, given that there is evidence from other studies that the elderly respond to social insurance benefits in their homeownership and headship decisions, we focus on a broader set of behavioral responses that include these outcomes. Second, because of measurement problems caused by the re-design of the CPS in 1994, we limit our analysis to 1995-2000. We discuss this in detail in the next section. Orsini (2007) focuses on a longer time period, 1988-2000, and does not account for the changes in the CPS format. Finally, we lay out an instrumental variable approach that utilizes state-by-calendar-year variation in Medicare reimbursement caps, measured using home health average expenditures per user as dictated by the legislation. Orsini (1997) instead uses a measure of policy restrictiveness developed by McKnight (2006), based on home health care visits per user, and a reduced-form approach. ${ }^{4}$

\section{Data Construction}

To identify the impact on housing and living arrangements from the reduction in home health benefits from BBA97, we draw data from the Current Population Surveys (CPS) of March, 1996 through 2001. The primary advantage of the CPS is that the Housing Vacancy Survey, which is the official government source of homeownership rates, is a derivative of the

\footnotetext{
${ }^{3}$ Unfortunately, McKnight could not study this, as informal care is not measured in the MCBS. Charles and Sevak (2005) and Mellor (2001), among others, have studied substitution via informal care.

${ }^{4}$ At the end of her analysis, Orsini presents a two-sample IV estimate of the impact of visits on living arrangements using her reduced-form estimates and McKnight's first-stage estimates. However, the IV strategy is not the focus of the analysis, as it is in our study.
} 
CPS, so that the CPS is the ideal survey data source to study for homeownership. The primary disadvantage is that the CPS only samples non-institutionalized individuals, thus omitting elderly in nursing homes. To the extent that the decline in Medicare funding for home health care from BBA97 resulted in substitution from home- and community-based to nursing home living, use of the CPS might induce sample-selection bias. For a number of reasons, we do not believe this occurred. We discuss this in detail in section VII below. ${ }^{5}$

Each March file is a cross-sectional, nationally representative sample of households. Following Engelhardt (2008), Engelhardt, Gruber, and Perry (2005) and Engelhardt and Gruber (2005, 2006), we define "elderly" as all individuals age 65 and older, all of whom are Medicare eligible, and we make a distinction between families and households. Specifically, a "family" inside of the CPS household is defined as the individual, his or her spouse (if any), and any children of the individual who are living in the household and are under the age of 18. Under this definition, there may be more than one "family" in a given CPS "household." This could occur if there are multiple non-married elderly living together or if an elderly individual resides with a non-elderly family.

Elderly families are defined as those families headed by an elderly individual. They make decisions about household headship and whether to engage in shared living arrangements. In contrast, elderly households are defined as those CPS households headed by an elderly individual. They make decisions about homeownership. ${ }^{6}$

The questions in the March CPS are about income earned in the previous calendar year, so that even though the survey data come from 1996-2001, the income data refer to 1995-2000. Even though the transition from IPS to PPS occurred in October, 2000, we follow McKnight (2006) and include calendar year 2000 in the sample. As we discuss below, our findings are robust to this assumption.

In addition, we do not use data prior to 1995. Specifically, in 1994 the CPS moved to a computer-assisted personal interview (CAPI) format, updated its sampling frame based on the

\footnotetext{
${ }^{5}$ Another disadvantage of the CPS is that it does not include measures of health status. In particular, one might expect that the reduction in Medicare generosity would have differentially affected elderly with high (relative to low) long-term care costs. McKnight (2006) was able to exploit this third dimension of variation in her analysis. We discuss our work on a separate paper using health measures in the Health and Retirement Study in the conclusion.

${ }^{6}$ The CPS only asks the homeownership question to the household head.
} 
1990 Census, introduced a new questionnaire, and instituted a number of other changes to the survey. Pitkin (1998) and Masnick, McArdle, and Belsky (1999) have analyzed the effect of these changes on measured trends in aggregate homeownership in the 1990s using the CPS. They found that, concurrent with these changes, there appears to be an unusually large increase in the number of households and the homeownership rate as measured in the CPS between 1994 and 1996. In addition, Masnick et al. found that these increases differed by age, state, and marital status in a way that suggested the measured changes in homeownership before versus after 1994 in the CPS may have been spurious. Because it is imperative that the estimation results not be driven by these survey changes and because the IPS was introduced well after the CPS revisions, we limit our sample to data starting in 1996, using data from 1995-the first year after the survey revision—as a robustness check. We describe this more below.

Pooled across all years, there are 51,856 observations on elderly households and 57,607 observations on elderly families in the analysis dataset. There are more elderly families than households because some elderly individuals live in shared arrangements in which they are not the household head. Table 1 shows descriptive statistics for selected variables in the analysis.

\section{Time-Series Evidence}

Figure 3 shows the simple time-series relationship between the frequency of shared living arrangements and Medicare home health expenditures per user for elderly families from 19952000 for the CPS analysis sample described above. There is a clear inverse relationship. As expenditures (the solid line) fell with the introduction of IPS in 1998, shared living among the elderly (the dashed lines) rose, both for all elderly and the widowed. Similarly, Figure 4 shows the time-series for household headship and Medicare home health expenditures per user for elderly families in this period. In general, as program generosity fell, so did headship. The evidence from both figures suggests that home health care program had important effects on elderly housing and living arrangements.

Figure 5 shows the evolution of the homeownership rate for elderly households for 19952000. Although it would be expected that greater generosity in long-term care would promote homeownership by allowing the elderly to age in place longer, there is no evidence for this in the 
simple time series. In fact, as program expenditures per user fell, homeownership actually rose, suggesting an inverse relationship. Overall, Figures 3-5 suggest some impact of home health care benefits on elderly living arrangements, but none on homeownership.

\section{Regression Framework and Identification}

There are two obvious drawbacks of the time-series analysis. First, the time series mask the substantial variation in home health care funding that occurred within states over time, due to the way the IPS was implemented. Second, other factors varying over time could be confounding those simple trends. Therefore, to better identify the impact of home health care benefits, we move to a regression framework using the micro-data.

Specifically, let $i, a, s, d$, and $t$ index the household, age, state of residence, Census division, and calendar year, respectively, and $\mathbf{x}$ denote a vector that contains a constant and demographic and housing cost variables. Our focal regression specification is for shared living arrangements,

$$
D_{\text {iast }}^{\text {SHARED }}=\theta b_{\text {st }}+\beta y_{\text {iast }}+\delta \mathbf{x}_{\text {iast }}+u_{\text {iast }},
$$

where $D^{\text {SHARED }}$ is a dummy variable that takes on a value of one if the elderly family is in a shared living arrangement and zero otherwise, and $u$ is a disturbance term. The explanatory variable, $y$, is log of after-tax total income. Following Engelhardt (2008), Engelhardt, Gruber, and Perry (2005) and Engelhardt and Gruber (2005, 2006), it refers to the sum of money income from all sources received by individuals in the family during the calendar year. Total taxes paid are defined as annual federal and state income and payroll taxes and are calculated for each family in the household based on demographic characteristics and the sources and amounts of income received by family members using the NBER's TAXSIM Calculator. The CPS does not have enough information on tax deductions to allow for a calculation of itemized deductions, so all tax-filing units were assumed to claim the standard deduction. After-tax family income is gross family income less family taxes paid; after-tax household income is defined as gross household income (the sum of gross family income across all families in the household) less household taxes paid (the sum of family taxes paid across all families in the household). All 
income measures were deflated into real 2001 dollars using the all-items Consumer Price Index (CPI).

The vector $\mathbf{x}$ includes dummy variables for the educational attainment of the head (high school diploma, some college, and college or advanced degree), marital status (married, widowed, and divorced in the pooled sample), white, and female. These explanatory variables control for any other trends in demographic characteristics that might be correlated with state expenditures and with housing and living arrangements. Following Engelhardt (2008), the usercost measure is that of Green and Vandell (1998) and incorporates federal tax rates calculated from NBER's TAXSIM calculator. Because the standard deduction may drive a wedge between the marginal and average cost of homeownership, the specification also includes an explanatory variable that is the real value of the standard deduction for each observation's tax filing status.

Finally, the key explanatory variable is $b$, the log of Medicare home health expenditures per user in that state and calendar year. Although we will often refer to this measure below as the generosity of the long-term care benefits, in practice, expenditures embody both the market value of the quality and quantity of the home health care services and probably to some extent differences in input costs—primarily nurses' labor costs-due to differences in the cost of living across locations that are not due to quality and quantity per se. Partly because of this, McKnight (2006) and Orsini (2007) used Medicare home health care visits per user to construct their focal explanatory variable. As illustrated in Figure 2, expenditures per user, participation, and visits per user track each other very closely, suggesting that the variation in expenditures per user is really measuring quality and quantity of home health services. Indeed, our results are not materially different if we use a measure based on visits, for example. McKnight (2006) had a similar finding. Overall, we believe that expenditures per user is the best measure for our purposes. We will return to this when we discuss our robustness checks below.

Because $b$ is expressed in logs, the key parameter, $\theta$, in (1) is a semi-elasticity and measures the impact on the frequency of shared living from a doubling of the generosity of benefits. The central hypothesis is that increases in benefits have no impact on living arrangements, $\theta=0$, versus the alternative that increases in benefits reduce the incidence of shared living, $\theta<0$. 
In principle, the parameters in (1) could be estimated with the micro-data using ordinary least squares (OLS) estimation of a linear probability model. In practice, unfortunately, there are two obvious sources of omitted-variable bias with such estimation. First, older individuals with a high demand for privacy, and, therefore, a low demand for shared living, might also have a high demand for long-term care benefits. Failure to adequately control for latent demand would lead to an omitted variable that would then be a confounder in the estimation, in this case, biasing the estimates away from zero, indicating a response to benefits that is too elastic. Second, the incidence of shared living also depends on the supply of potential co-residents, such as children and, especially, daughters (Wolf and Soldo, 1988; Wolf, 1994, 1995). If high benefit states also have a greater supply of potential co-residents (another confounder) then simple estimates would be biased toward zero, indicating a response to benefits that is too inelastic. ${ }^{7}$ Overall, each of these problems would lead to biased and inconsistent regression-based estimates of the impact of home health benefits, although the net sign of the bias is unclear.

To circumvent these problems, we attempt to isolate the causal impact of home health benefits on housing and living arrangements by the use of an instrumental-variable estimation approach. Technically, IPS capped agency costs using the 75/25 weighted average described above. However, as McKnight (2006) stresses, the agency-level caps when aggregated up to the state level will imply state-level limitations on reimbursement after the law change, too. Therefore, we define the instrument, $Z$, as

$$
Z_{s t} \equiv \% \Delta \operatorname{Cap}_{s} \times D_{t}^{\text {Post } 1997},
$$

which is the product of the percentage change in the home health care reimbursement cap in each state as dictated by BBA97 interacted with a dummy variable, $D^{\text {Post1997 }}$, that takes on a value of one after the IPS was implemented in 1998 and zero otherwise. Let $P^{1994}$ be the annual Medicare home health care payment per user in 1994, then under IPS the percentage change in the home health care reimbursement cap for a state is

$$
\% \Delta \operatorname{Cap}_{s} \equiv \frac{\left(0.75 P_{s}^{1994}+0.25 P_{d}^{1994}\right)-P_{s}^{1994}}{P_{s}^{1994}} .
$$

\footnotetext{
${ }^{7}$ The March CPS does not contain any fertility information that would allow the construction of the number of children or daughters as a measure of the potential supply of co-residents.
} 
That is, before IPS, effectively actual costs were reimbursed; after IPS, reimbursements were capped by weighted average of the state's 1994 average payment (75\% weight) and the 1994 Census division's average payment (25\% weight). From the perspective of 1998-2000, the postlaw-change period, the 1994 payments are predetermined and, therefore, exogenous, so that, in principle, $Z$, is a valid instrument.

Column 1 of Table 2 shows the 1994 home health care payments by Census division and state; column 2 shows the associated percentage change in the reimbursement cap from the movement to IPS. Across states, there is substantial variation in the generosity of reimbursement due to BBA97. States with above-Census-division-average payments in 1994 got their funding restricted under IPS. Those with below-Census-division-average payments in 1994 got the opposite.

Following Engelhardt (2008), we specify the disturbance term, $u$, as

$u_{\text {iast }}=\omega_{s}+\gamma_{t}+\kappa_{a}+\varphi_{a t}+v_{\text {iast }}$,

where $\omega$ is a vector of state effects, $\gamma$ is a vector of calendar-year effects, $\kappa$ is a vector of effects for the age of the head (by single year of age); $\phi$ is a linear year-of-birth trend; and $v$ is white noise. The full set of age dummies controls for differences across single years of age in housing and living arrangements; the state dummies control for any differences across states; the year dummies control for any general national time trends; and the year-of-birth trend controls for any linear trend in across years of birth. Therefore, after controlling for state and calendar year, the IV estimates are identified by state-by-time variation in the instrument from changes in the reimbursement cap that began after 1997 due to the switch to IPS in the BBA97.

\section{Estimation Results}

Panels A-D of Table 3 show the OLS, first-stage, reduced-form, and IV estimates, respectively, of the effect of Medicare home health benefits on the frequency of shared living arrangements by marital status for the baseline specification in (1), estimated for 1996-2000. Each cell of the table corresponds to a different regression and shows the parameter estimate, $\hat{\theta}$, 
with respect to our measure of benefit generosity, the log real expenditure per user, $b{ }^{8}$ Robust standard errors that are clustered by state are shown in parentheses. Elasticities evaluated at the sample mean are shown in brackets.

Column 1 begins with the subsample of widowed elderly, the largest group and the one that has garnered the greatest amount of policy attention. In Panel A, the OLS estimate of $\theta$ is -0.026 and can be interpreted as follows: when home health care benefits double, the likelihood that the typical elderly household resides in a shared living arrangement falls by 2.6 percentage points (although this effect is not statistically different from zero). Relative to a sample mean incidence of shared living of $29.7 \%$, this implies an elasticity of shared living to benefits of -0.09 , which is economically quite small.

Unfortunately, the OLS estimate might be biased and inconsistent due to omitted variables. Panel B shows the first-stage estimate-the first-stage fit is excellent, with a partial Fstatistic of 9.9. Panel C shows the reduced-form estimate, which is negative and statistically significant from zero. It is akin to a difference-in-difference estimate of the impact of the law change, comparing the shared living response for those in states with large versus small changes in the reimbursement cap, before versus after the law change. ${ }^{9}$ This estimate indicates that the incidence of shared living arrangements fell substantially in states that experienced an increase in the reimbursement cap due to the implementation of the IPS after 1997.

Panel D shows the IV estimate, which, compared to the OLS estimate, rises (in absolute value) substantially to -0.265 and is statistically significant at the $4 \%$ level. The implied elasticity, shown in brackets is -0.89 . This indicates the elderly are very responsive in their living arrangements to long-term care benefits. A comparison of the results in panels A and D suggests there is substantial bias in estimates that fail to instrument.

The IV estimate implies that a $10 \%$ increase in benefits reduces shared living among the widowed by $8.9 \%$. The average change in the reimbursement cap after the law change was $1.66 \%$. The IV estimate in panel D implies that a 1.66\% change in benefits would lead to a $1.48 \%$ (not percentage point) change in shared living. To put this in context, based on the index values in Figure 3, shared living rose by about 4\% among the widowed, so that the average

\footnotetext{
${ }^{8}$ The estimates for the full set of parameters for all specifications are available upon request from the authors.

${ }^{9}$ McKnight (2006) and Orsini (2007) both estimate reduced-form relationships.
} 
change in home health care benefits from the switch to IPS can explain about 37\% (i.e., $0.37=1.48 / 4$ ) of the time-series increase in shared living among the widowed in the 1996-2000 period shown in the figure.

\section{Robustness Checks}

We performed a series of robustness checks. First, we altered the sample period from 1996-2000 to 1995-1999. The associated IV estimate of $\theta$, was -0.19 , significant at the $7 \%$ level, with an implied elasticity of -0.64 , qualitatively similar to what was found in panel D. Second, because there might be other factors moving over time within states correlated with the instrument, we estimated a richer specification, shown in panel E.

We focus on two obvious confounders related to care in skilled nursing facilities, a substitute for home care. The primary payer for long-term care is Medicaid, which varies by state, with the bulk of expenditures going toward nursing home care. In panel E, we include a control for state-by-calendar-year log real Medicaid expenditure on the elderly, based on data for 1996-2000 taken from various issues of the Medicare and Medicaid Statistical Supplement. Unfortunately, the Medicaid data are not available at the state level prior to 1996, so we could not extend this analysis back to $1995 .^{10}$

Medicare also reimburses for care in skilled nursing facilities, although the rules differ from those of Medicaid. In particular, Medicare covers costs as long as the nursing home care occurs within 30 days of a hospital stay for acute care that lasted three days or longer. The number of skilled-nursing-facility days is limited to 100. To account for the possibility that home health care expenditures are changing within states over time in a manner that is also correlated with changes in skilled nursing, we control for state-by-calendar-year log real Medicare expenditures per user on skilled nursing facilities taken from various issues of the Medicare and Medicaid Statistical Supplement.

Another important advantage of including these additional controls has to do with the concern we outlined above about the key explanatory variable, $b$, the log of Medicare home health expenditures per user: that our estimates thus far may be predicated on both differences in

\footnotetext{
${ }^{10}$ This data limitation is why we originally limited our sample to 1996-2000, as discussed in section IV on data construction.
} 
benefit generosity and differences in input costs, primarily the cost of nurses' labor input. Because the elasticity of substitution between nurses in home health care and nurses in skilled nursing facilities is very high, changes over time within states in labor costs that might have been contaminating the estimates of $\theta$ based on expenditures per user will now be accounted for by the inclusion of the additional Medicare control.

With these additional controls, the IV estimate in panel $\mathrm{E}$ of $\theta$ is -0.338 , significant at the $2.5 \%$ level. The implied elasticity is -1.13 . Again, these results suggest that elderly living arrangements are quite responsive to home health benefits.

Column 2 of the table gives a parallel set of estimation results for the other major marital group, married elderly. The married have a baseline IV estimated elasticity of shared living to home health benefits of -0.4 . Not surprisingly, this is much less elastic than the widowed and not statistically different than zero. Finally, column 3 of the table gives estimation results for all marital groups combined: the widowed, the married, as well as the divorced and never married elderly, for whom the sample sizes were too small for separate estimation. Across all elderly, the IV estimated elasticity of shared living to benefits ranges from -0.58 (in panel D) to -0.83 (in panel E) and is statistically different than zero at conventional levels of significance.

As outlined above, a potential limitation of our approach is that the CPS does not interview institutionalized individuals, thus omitting the elderly in nursing homes. To the extent that the decline in Medicare funding for home health care from BBA97 resulted in substitution from home- and community-based to nursing home living, use of the CPS might induce sampleselection bias. We do not believe this in an important concern for our results for three reasons. First, if there was such substitution, we should observe a marked increase in nursing home use after 1997. Figure 6 plots the number of elderly in Medicaid-funded skilled nursing facilities during our sample period. In contrast to the substitution hypothesis, nursing home use actually fell uniformly across this period. Second, when we regress the log of the number of elderly in Medicaid-funded skilled nursing facilities using state-by-calendar-year data from the Medicare and Medicaid Statistical Supplement on our instrument and the other explanatory variables in our model, the parameter estimate with respect to the instrument is 0.08 , an economically small magnitude, and a standard error of 0.07 , not statistically different from zero. Thus, there is no relationship between nursing home use and the law change in our sample. Finally, in her 
regression analysis, McKnight (2006) examined possible links between the adoption of the IPS and spending on Medicaid home- and community-based services and found neither an economically important nor a statistically significant relationship.

A related potential source of selection bias is differential mortality. The CPS does not track individuals until death. To the extent that the decline in Medicare funding for home health care from BBA97 was associated with poorer health and relatively higher mortality for the elderly after (relative to before) the law change, then use of the CPS might induce sampleselection bias. Unfortunately, we have no direct way of assessing this in our data. However, we note that McKnight (2006) using the MCBS data found no discernable impact of the decline in home health care from BBA97 on elderly health (among those living) and no impact on mortality. Based on this evidence, we do not believe this in an important concern about our results.

\section{Impact on Household Headship}

Shared living can occur in two forms: a co-resident can become part of the elderly family's household, or the elderly family can become part of the co-resident's household. Table 4 examines the extent to which the changes in living arrangements found in Table 3 are associated with changes in household headship by the elderly. Specifically, Table 4 shows the IV estimates of the effect of benefits on the likelihood of headship for elderly families by marital status for a headship specification similar to (1):

$$
D_{\text {iast }}^{H E A D}=\theta b_{\text {st }}+\beta y_{\text {iast }}+\delta \mathbf{x}_{\text {iast }}+u_{\text {iast }},
$$

where $D^{H E A D}$ is a dummy variable that equals one if the head of the elderly family is also the head of the household and zero otherwise. Each cell of the table corresponds to a different

regression and shows $\hat{\theta}$, the parameter estimate with respect to log home health care expenditures per user; robust standard errors that are clustered by state are shown in parentheses; and, elasticities evaluated at the sample means are shown in brackets. Panel A gives the baseline IV estimates of $\theta$; panel B gives the IV estimates with additional state-by-calendar-year controls for log real expenditures on Medicare skilled nursing facilities and Medicaid spending on the elderly, respectively. 
Across all marital groups and in both panels, there is little evidence that changes in home health care benefits alter household headship decisions. Most of the estimated elasticities are economically quite small (very inelastic), and none are statistically different from zero at conventional levels of significance. These results suggest that changes in shared living among the elderly in response to home health care occur because a co-resident becomes part of the elderly family’s household.

\section{Impact on Homeownership}

Our analysis concludes by examining the extent to which home health care benefits affect elderly homeownership. While there are many housing dimensions on which the elderly could adjust behavior, including maintenance, structure type, and home modifications, homeownership is the only housing outcome consistently measured in the CPS. In particular, home health care benefits may allow elderly homeowners to age in place longer, forestalling health-related laterlife housing transitions (Venti and Wise, 1989, 1990, 2000, 2001). To explore this, Table 5 shows the IV estimates of the effect of log real expenditures on homeownership for elderly households by marital status for a specification similar to (1) and (5):

$$
D_{\text {iast }}^{\text {OWN }}=\theta b_{\text {st }}+\beta y_{\text {iast }}+\delta \mathbf{x}_{\text {iast }}+u_{\text {iast }},
$$

where $D^{O W N}$ is a dummy variable that equals one if the elderly household is a homeowner and zero otherwise. Each cell of the table corresponds to a different regression and shows $\hat{\theta}$, the parameter estimate with respect to log home health care expenditures per user; robust standard errors that are clustered by state are shown in parentheses; and, elasticities evaluated at the sample means are shown in brackets. Panel A gives the baseline IV estimates of $\theta$; panel B gives the IV estimates with additional state-by-calendar-year controls for log real expenditures on Medicare skilled nursing facilities and Medicaid spending on the elderly, respectively.

For the two primary marital groups, widowed and married, there is little statistically significant evidence that greater home health care benefits raise elderly homeownership. However, in the pooled sample in column 3, the sample size is sufficient such that there is enough precision to reject the null hypothesis of no effect in favor of the alternative that greater 
home health care benefits raise homeownership at conventional levels of significance. Over all elderly, the IV estimated elasticity of homeownership with respect to benefits is about 0.22 .

\section{Summary and Caveats}

There are three primary findings. First, the weight of empirical evidence from our analysis suggests that the changes in the supply of long-term care insurance through Medicare home health care benefits that occurred in the late 1990s had an economically important impact on elderly living arrangements. We estimate the elasticity of shared living to benefits to be -0.7 over all elderly and -1 for widowed elderly. Second, there seems to have been little impact on household headship among the elderly. This suggests that the bulk of the shared-living response occurred through co-residents living in elderly households. Finally, there is some weak evidence that increases in benefits raised homeownership.

Overall, living arrangements appear to quite responsive to home health care benefits. Our estimates are much larger than those from the early 1980's by Hoerger, Picone, and Sloan (1996) and Pezzin, Kemper, and Reschovsky (1996)—although the scope of the data and the methodologies vary substantially across these studies_-but similar in magnitude to estimates from the Social Security literature (Michael, Fuchs, and Scott, 1976; McGarry and Schoeni, 2000; Engelhardt, Gruber, and Perry, 2005; and Engelhardt, 2008). Furthermore, our results are qualitatively consistent with those of McKnight (2006) — who found that while private out-ofpocket medical expenditures rose with the decline in Medicare home health expenditures, there was no impact on elderly health—if families substituted informal care for formal care from home health care agencies, part of which occurred through shared living arrangements, and Orsini (2007), who found a fairly substantial impact on shared living from the law change.

One important limitation is that the CPS does not include measures of health status. In particular, one might expect that the reduction in Medicare generosity would have differentially affected elderly with high (relative to low) long-term care costs. McKnight (2006) was able to exploit this third dimension of variation in her analysis, because the MCBS has information on health status. In a separate paper, we are using information on health status, out-of-pocket expenditures, informal care, and detailed data on housing characteristics from the Health and 
Retirement Study (HRS) to examine the impact of the movement to IPS on the housing, living arrangements, and informal care of the elderly in finer detail. The HRS has some other desirable features, too. It surveys the institutionalized elderly and tracks individuals until death, so that we will be able to directly assess whether the movement to IPS resulted in substitution of nursing home for home health care or differential mortality. It also measures maintenance, structure type, and home modifications that will help us better assess housing responses to home health care benefits.

A final caveat has to do with external validity. While we believe we have identified the impact of public long-term care insurance for home health care and have demonstrated that such insurance can have important impacts on housing and living arrangements, it is unclear how our findings might generalize to Medicaid, which is the primary funding source for long-term care in general and nursing home care in particular. The impact of Medicaid on the housing and living arrangements of the elderly (Coe, 2007; Greenhalgh-Stanley, 2008), on the demand for private long-term care insurance (Brown and Finkelstein, 2007), and the interplay between housing wealth and the demand for long-term care insurance and annuities (Davidoff, 2008a, 2008b) are important directions for future research. 


\section{References}

Brown, Jeffrey R., and Amy Finkelstein, "Why is the Market for Long-Term Care Insurance So Small?” Journal of Public Economics 91 (2007): 1967-1991.

Brown, Jeffrey R., and Amy Finkelstein, “The Interaction of Public and Private Insurance: Medicaid and the Long-Term Care Insurance Market,” NBER Working Paper No. 10989, 2004.

Brown, Jeffrey R., Norma B. Coe, and Amy Finkelstein, "Medicaid Crowd-Out of Private LongTerm Care Insurance Demand: Evidence from the Health and Retirement Survey,” NBER Working Paper No. 12536, 2006.

Charles, Kerwin Kofi, and Purvi Sevak, “Can Family Caregiving Substitute for Nursing Home Care?” Journal of Health Economics 24 (2005): 1174-1190.

Coe, Norma, “Financing Nursing Home Care: New Evidence on Spend-Down Behavior,” Mimeo., Tilburg University, 2007.

Costa, Dora L., “A House of Her Own: Old Age Assistance and Living Arrangements of Older Nonmarried Women,” Journal of Public Economics, 72 (1999): 39-60.

Davidoff, Thomas, and Gerd Welke "Selection and Moral Hazard in the Reverse Mortgage Market,” Mimeo., UC-Berkeley, 2007.

Davidoff, Thomas, “Housing, Health, and Annuities,” Mimeo., UC-Berkeley, 2008a.

Davidoff, Thomas, “Illiquid Housing as Self-Insurance: The Case of Long-Term Care,” Mimeo., UC-Berkeley, 2008b.

Dietz, Robert D., and Donald R. Haurin, "The Social and Private Micro-Level Consequences of Homeownership,” Journal of Urban Economics 54 (2003): 401-450.

Engelhardt, Gary V., “Housing Older Americans,” Fannie Mae Papers, Volume IV, Issue 1, January, 2005.

Engelhardt, Gary V., “Social Security and Elderly Homeownership,” Journal of Urban Economics 63 (2008): 280-305.

Engelhardt, Gary V., and Jonathan Gruber, “Social Security and Elderly Well-Being in the United States” Mimeo., MIT, 2005.

Engelhardt, Gary V., and Jonathan Gruber, "Social Security and the Evolution of Elderly Poverty” in Alan Auerbach, David Card, and John Quigley, eds. Poverty, Public Policy, and the Distribution of Income, Russell Sage Press, forthcoming, 2006. 
Engelhardt, Gary V., Jonathan Gruber, and Cynthia D. Perry, "Social Security and Elderly Living Arrangements,” Journal of Human Resources 40:2 (2005): 354-372.

Feinstein, Jonathan, and Daniel McFadden, “The Dynamics of Housing Demand by the Elderly: Wealth, Cash Flow, and Demographic Effects," in David Wise, ed., The Economics of Aging (Chicago: University of Chicago Press), 1989, 55-92.

Green, Richard K., and Kerry D. Vandell, “Giving Households Credit: How Changes in the U.S. Tax Code Could Promote Homeownership,” Regional Science and Urban Economics 29 (1999): 419-444.

Greenhalgh-Stanley, Nadia, “The Impact of TEFRA Liens on Housing and Asset Decisions Among the Elderly,” Mimeo., Syracuse University, 2008.

Health Care Financing Administration, Various Years. Medicare and Medicaid Statistical Supplement (Washington, D.C.: United States Department of Health and Human Services).

Hoerger, Thomas J., Gabriel A. Picone, and Frank A. Sloan, "Public Subsidies, Private Provision of Care, and the Living Arrangements of the Elderly," Review of Economics and Statistics 78 (1996): 428-440.

Kutty, Nandinee, “The Scope for Poverty Alleviation Among Elderly Homeowners in the U.S. Through Reverse Mortgages,” Urban Studies 35 (1998): 113-130.

Masnick, George S., Nancy McArdle, and Eric S. Belsky, “A Critical Look at Rising Homeownership Rates in the United States Since 1994,” Harvard University Joint Center for Housing Studies Paper No. W99-2, 1999.

Mayer, Christopher, and Katerina Simons, "Reverse Mortgages and the Liquidity of Housing Wealth,” Journal of the American Real Estate and Urban Economics Association, 22 (1994): 235-255.

McGarry, Kathleen, and Robert F. Schoeni, "Social Security, Economic Growth, and the Rise in Elderly Widows’ Independence in the Twentieth Century,” Demography, 37 (2000), 221236.

McKnight, Robin, "Home Care Reimbursement, Long-Term Care Utilization, and Health Outcomes,” Journal of Public Economics 90 (2006): 293-323.

Megbolugbe, Isaac, Jarjisu Sa-Aadu, and James D. Shilling, “Oh, Yes, the Elderly Will Reduce Housing Equity Under the Right Circumstances,” Journal of Housing Research 8 (1997): 53-74. 
Megbolugbe, Isaac, Jarjisu Sa-Aadu, and James D. Shilling, "Elderly Female-Headed Households and the Decision to Trade Down," Journal of Housing Economics 8 (1999): 285-300.

Mellor, Jennifer, "Long-Term Care and Nursing Home Coverage: Are Adult Children Substitutes for Insurance Policies?” Journal of Health Economics 20 (2001): 527-547.

Merrill, Sally, "Home Equity and the Elderly,” in Henry Aaron and Gary Burtless, eds., Retirement and Economic Behavior (Washington, DC: Brookings Institution), 1984.

Michael, Robert T., Victor R. Fuchs, Sharon R. Scott, "Changes in the Propensity to Live Alone,” Demography, 17 (1980): 39-56.

Norton, Edward C., "Long-Term Care,” in A.J. Cuyler and J.P. Newhouse (eds.) Handbook of Health Economics, Volume 1 (Elsevier: Amsterdam), 2000, pp. 955-994.

Orsini, Chiara, "Changing the Way the Elderly Live: Evidence from the Home Health Care Market in the United States,” Mimeo., University of Maryland, 2007.

Pezzin, Liliana E., Peter Kemper, and James Reschovsky, "Does Publicly Provided Home Care Substitute for Family Care? Experimental Evidence with Endogenous Living Arrangements,” Journal of Human Resources 31 (1996): 650-676.

Pitkin, John R., "Changes in Homeownership and Households, 1993 to 1995: An Evaluation of Estimates from the Current Population Survey,” Journal of Housing Research 9 (1998): 317-326.

Reschovsky, James, “Residential Immobility of the Elderly,” Real Estate Economics 18:2 (1990): 160-183.

United States Congress, Committee on Ways and Means, Green Book, Government Printing Office: Washington, D.C., 2004.

Venti, Steven F., and David A. Wise, “Aging, moving, and housing wealth,” in: D. Wise (Ed.) The Economics of Aging, University of Chicago Press, Chicago, IL, 1989, pp. 9-48.

Venti, Steven F., and David A. Wise, "But they don't want to reduce housing equity," in: D. Wise (Ed.) Issues in the Economics of Aging, University of Chicago Press, Chicago, IL, 1990, pp. 13-29.

Venti, Steven F., and David A. Wise, “Aging and the Income Value of Housing Wealth,” Journal of Public Economics 44 (1991): 371-397.

Venti, Steven F., and David A. Wise, “Aging and Housing Equity,” NBER Working Paper No. 7882, 2000. 
Venti, Steven F., and David A. Wise, “Aging and Housing Equity: Another Look,” NBER Working Paper No. 8608, 2001.

Wolf, Douglas A., “The Elderly and Their Kin: Patterns of Availability and Access,” in Linda G. Martin and Samuel H. Preston, eds., Demography of Aging (Washington, D.C.: National Academy Press), 1994, 146-194.

Wolf, Douglas A., "Changes in the Living Arrangements of Older Women: An International Study,” The Gerontologist, 35 (1995): 724-731.

Wolf, Douglas A. and Beth J. Soldo, "Household Composition Choices of Older Unmarried Women,” Demography, 25 (1998): 387-403. 
Table 1. Sample Means for Selected Variables for Elderly Families and Households by Marital Status, with Standard Deviations in Parentheses, Age 65 and Older, for 1996-2000

\begin{tabular}{|c|c|c|c|}
\hline & (1) & $\begin{array}{c}(2) \\
\text { Sample }\end{array}$ & (3) \\
\hline Variable & Widowed & Married & Pooled \\
\hline \multicolumn{4}{|l|}{ A. Elderly Families } \\
\hline Shared Living Arrangement & 0.297 & 0.164 & 0.249 \\
\hline Household Head & 0.865 & 0.981 & 0.908 \\
\hline Log Real After-Tax Income & 2.590 & 3.381 & 2.920 \\
\hline High School Degree & 0.344 & 0.322 & 0.331 \\
\hline Some College & 0.157 & 0.184 & 0.172 \\
\hline College Degree & 0.064 & 0.121 & 0.091 \\
\hline Female & 0.816 & 0.183 & 0.521 \\
\hline White & 0.872 & 0.916 & 0.885 \\
\hline Number of Observations & 24,734 & 23,798 & 57,607 \\
\hline \multicolumn{4}{|l|}{ B. Elderly Households } \\
\hline Homeowner & 0.736 & 0.910 & 0.792 \\
\hline Log Real After-Tax Income & 2.640 & 3.396 & 2.981 \\
\hline High School Diploma & 0.348 & 0.321 & 0.331 \\
\hline Some College & 0.168 & 0.185 & 0.180 \\
\hline College Degree & 0.066 & 0.122 & 0.095 \\
\hline Female & 0.817 & 0.174 & 0.500 \\
\hline White & 0.882 & 0.915 & 0.893 \\
\hline Number of Observations & 21,241 & 23,150 & 51,856 \\
\hline
\end{tabular}


Table 2. Change in Medicare Home Health Care Reimbursement by State from the Introduction of the Interim Payment System in the Balanced Budget Act of 1997

\begin{tabular}{|c|c|c|}
\hline & (1) & (2) \\
\hline Region/State & $\begin{array}{l}1994 \text { Program } \\
\text { Payment Per } \\
\text { Person Served }\end{array}$ & $\begin{array}{c}\text { Percentage } \\
\text { Change in } \\
\text { Reimbursement } \\
\text { Cap }\end{array}$ \\
\hline New England & 4,023 & \\
\hline Connecticut & 4,367 & -1.97 \\
\hline Maine & 3,365 & 4.89 \\
\hline Massachusetts & 4,328 & -1.76 \\
\hline New Hampshire & 2,823 & 10.62 \\
\hline Rhode Island & 3,753 & 1.80 \\
\hline Vermont & 2,635 & 13.17 \\
\hline Middle Atlantic & 3,031 & \\
\hline New Jersey & 2,702 & 3.04 \\
\hline New York & 3,334 & -2.27 \\
\hline Pennsylvania & 2,899 & 1.14 \\
\hline East North Central & 3,272 & \\
\hline Illinois & 3,386 & -0.84 \\
\hline Indiana & 4,000 & -4.55 \\
\hline Michigan & 3,285 & -0.10 \\
\hline Ohio & 3,014 & 2.14 \\
\hline Wisconsin & 2,586 & 6.63 \\
\hline West North Central & 2,871 & \\
\hline Iowa & 2,280 & 6.48 \\
\hline Kansas & 3,486 & -4.41 \\
\hline Minnesota & 2,518 & 3.50 \\
\hline Missouri & 3,161 & -2.29 \\
\hline Nebraska & 2,566 & 2.97 \\
\hline North Dakota & 2,380 & 5.16 \\
\hline South Dakota & 2,402 & 4.88 \\
\hline South Atlantic & 4,066 & \\
\hline Delaware & 2,478 & 16.02 \\
\hline District of Columbia & 3,462 & 4.36 \\
\hline Florida & 4,595 & -2.88 \\
\hline Georgia & 5,215 & -5.51 \\
\hline Maryland & 2,859 & 10.55 \\
\hline North Carolina & 3,287 & 5.92 \\
\hline South Carolina & 3,764 & 2.01 \\
\hline Virginia & 3,168 & 7.09 \\
\hline West Virginia & 2,819 & 11.06 \\
\hline East South Central & 5,329 & \\
\hline Alabama & 5,107 & 1.09 \\
\hline Kentucky & 3,369 & 14.54 \\
\hline Mississippi & 5,316 & 0.06 \\
\hline Tennessee & 6,508 & -4.53 \\
\hline
\end{tabular}




$\begin{array}{lcc}\text { West South Central } & 5,877 & \\ \text { Arkansas } & 3,586 & 15.97 \\ \text { Louisiana } & 6,700 & -3.07 \\ \text { Oklahoma } & 6,035 & -0.65 \\ \text { Texas } & 5,977 & -0.42 \\ & & \\ \text { Mountain } & 4,050 & \\ \text { Arizona } & 3,932 & 0.75 \\ \text { Colorado } & 4,091 & -0.25 \\ \text { Idaho } & 3,347 & 5.25 \\ \text { Montana } & 3,052 & 8.17 \\ \text { Nevada } & 4,466 & -2.33 \\ \text { New Mexico } & 3,355 & 5.18 \\ \text { Utah } & 5,481 & -6.52 \\ \text { Wyoming } & 4,309 & -1.50 \\ & & \\ \text { Pacific } & 3,862 & -2.73 \\ \text { Alaska } & 4,336 & -1.31 \\ \text { California } & 4,075 & 2.20 \\ \text { Hawaii } & 3,549 & 5.29 \\ \text { Oregon } & 3,188 & -0.56 \\ \text { Washington } & 3,951 & \end{array}$

Note: The table shows the percentage change in the reimbursement cap after the 1997 law change. The source for column 1 is Table 48 in Health Care Financing Administration (1996). The figures in column 2 are the authors' calculations. 
Table 3. Ordinary Least Squares, First-Stage, Reduced-Form, and Instrumental Variable Parameter Estimates from the Linear Probability Model of the Effect of Medicare Home Health Care Expenditures Per User on Shared Living Arrangements for Elderly Families, by Marital Status, Using Data for 1996-2000 from the CPS, Elasticity in Brackets, Standard Errors Clustered by State in Parentheses

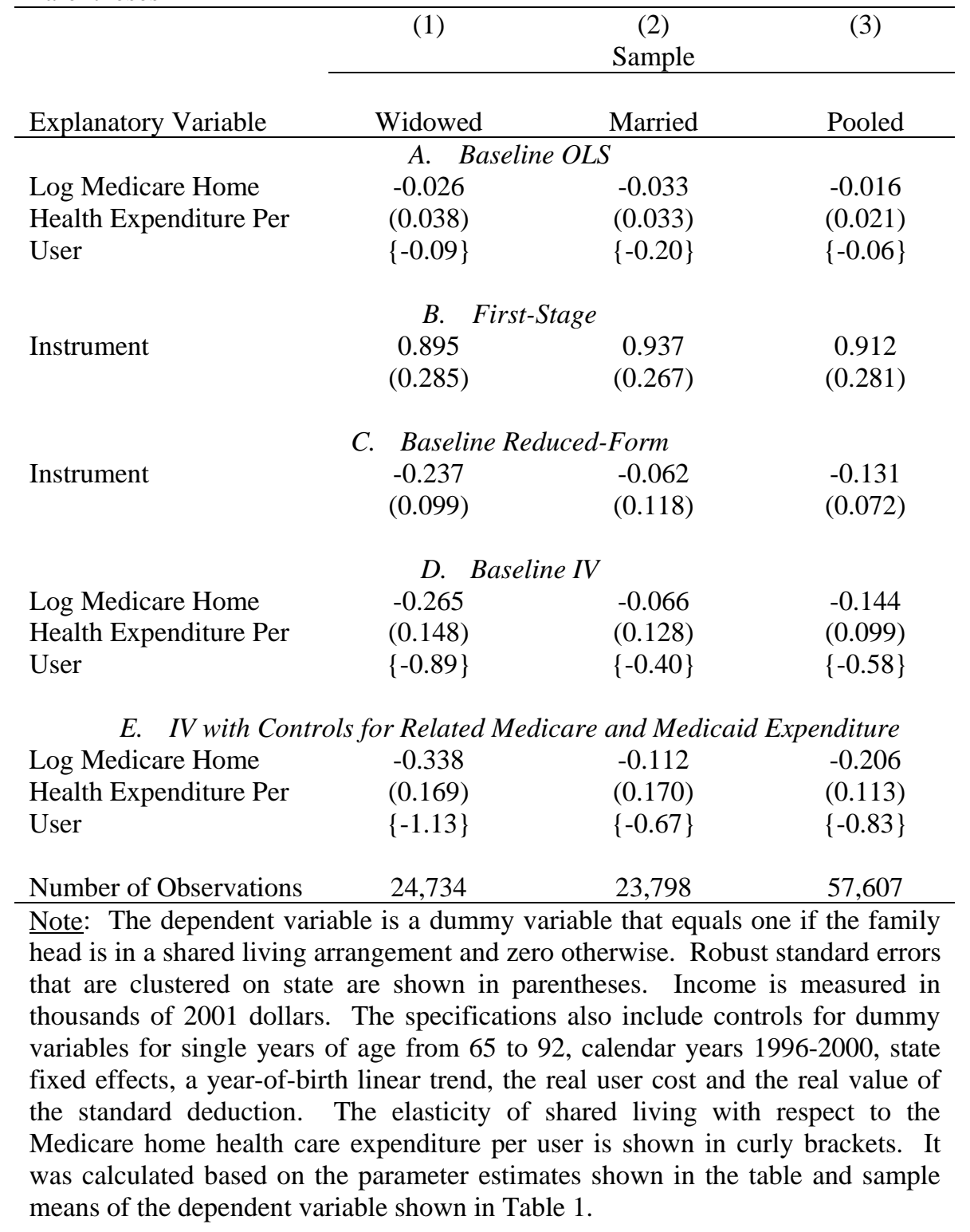


Table 4. Instrumental Variable Parameter Estimates from the Linear Probability Model of the Effect of Medicare Home Health Care Expenditures Per User on Household Headship for Elderly Families, by Marital Status, Using Data for 1996-2000 from the CPS, Elasticity in Brackets, Standard Errors Clustered by State in Parentheses

\begin{tabular}{|c|c|c|c|}
\hline \multirow[b]{2}{*}{ Explanatory Variable } & \multicolumn{3}{|c|}{$\begin{array}{c}(2) \\
\text { Sample }\end{array}$} \\
\hline & Widowed & Married & Pooled \\
\hline \multicolumn{4}{|c|}{ A. $\quad$ Baseline IV } \\
\hline Log Medicare Home & 0.107 & 0.005 & 0.036 \\
\hline Health Expenditure Per & $(0.088)$ & $(0.036)$ & $(0.053)$ \\
\hline User & $\{0.12\}$ & $\{0.005\}$ & $\{0.04\}$ \\
\hline \multicolumn{4}{|c|}{ B. IV with Controls for Related Medicare and Medicaid Expenditure } \\
\hline Log Medicare Home & 0.142 & 0.007 & 0.045 \\
\hline Health Expenditure Per & $(0.104)$ & $(0.051)$ & $(0.066)$ \\
\hline User & $\{0.16\}$ & $\{0.007\}$ & $\{0.05\}$ \\
\hline Number of Observations & 24,734 & 23,798 & 57,607 \\
\hline \multicolumn{4}{|c|}{$\begin{array}{l}\text { Note: The dependent variable is a dummy variable that equals one if the family } \\
\text { head is in a shared living arrangement and zero otherwise. Robust standard errors } \\
\text { that are clustered on state are shown in parentheses. Income is measured in } \\
\text { thousands of } 2001 \text { dollars. The specifications also include controls for dummy } \\
\text { variables for single years of age from } 65 \text { to } 92 \text {, calendar years 1996-2000, state } \\
\text { fixed effects, a year-of-birth linear trend, the real user cost and the real value of } \\
\text { the standard deduction. The elasticity of shared living with respect to the } \\
\text { Medicare home health care expenditures per user is shown in curly brackets. It } \\
\text { was calculated based on the parameter estimates shown in the table and sample } \\
\text { means of the dependent variable shown in Table } 1 \text {. }\end{array}$} \\
\hline
\end{tabular}


Table 5. Instrumental Variable Parameter Estimates from the Linear Probability Model of the Effect of Medicare Home Health Care Expenditures Per User on Homeownership for Elderly Households, by Marital Status, Using Data for 19962000 from the CPS, Elasticity in Brackets, Standard Errors Clustered by State in Parentheses

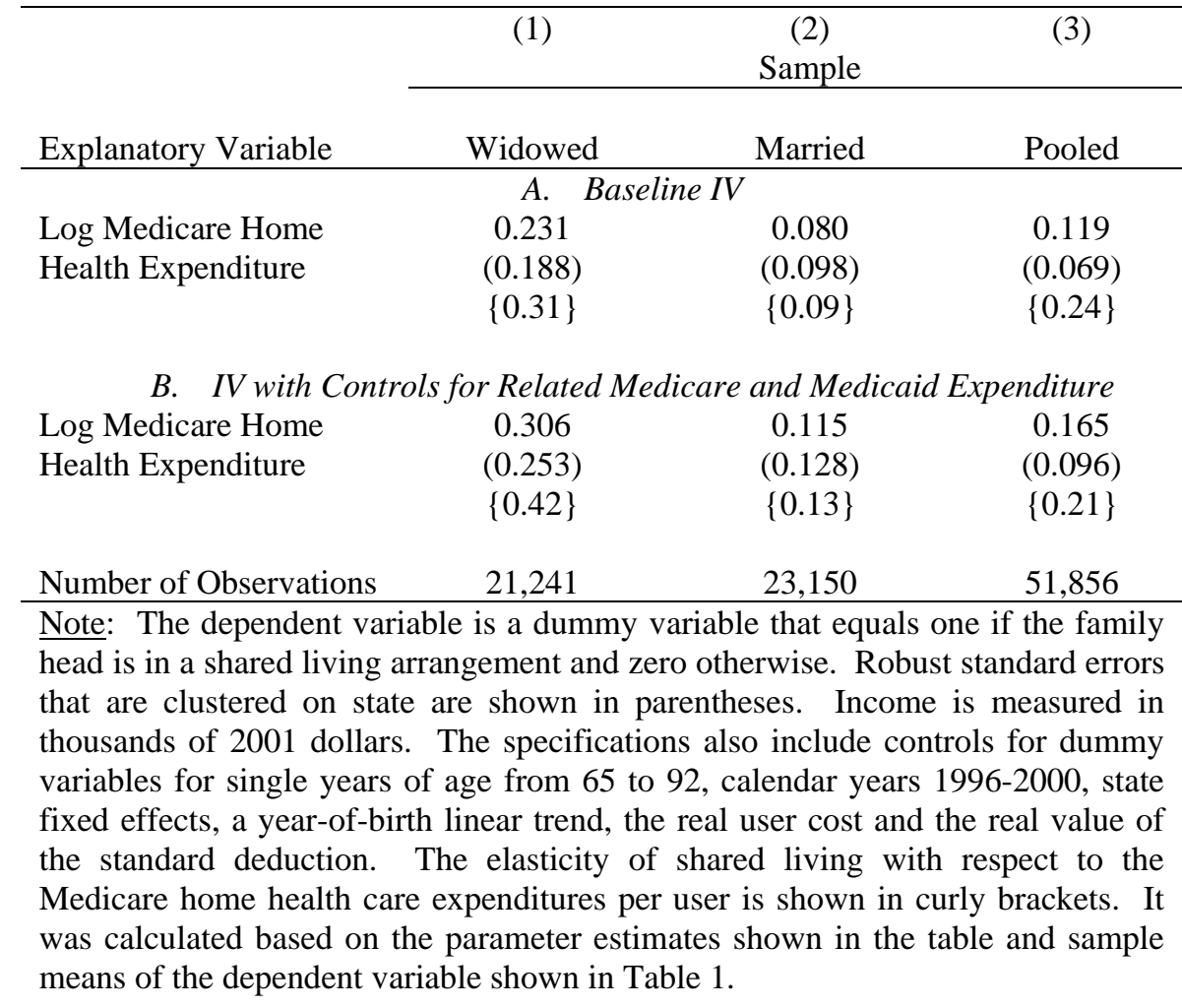


Figure 1. Real Annual Medicare Home Health Program Expenditures

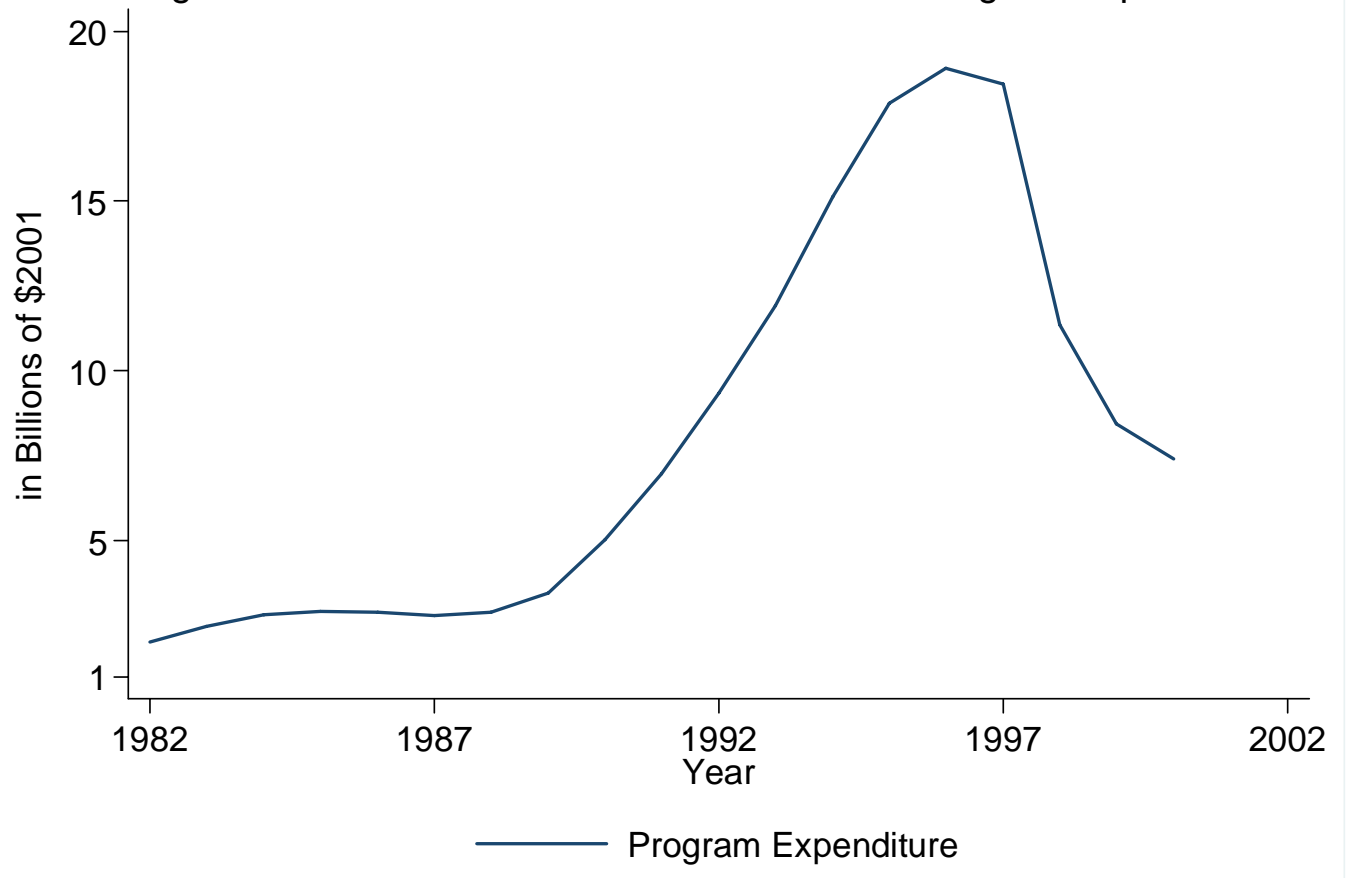


Figure 2. Medicare Home Health Program Payments

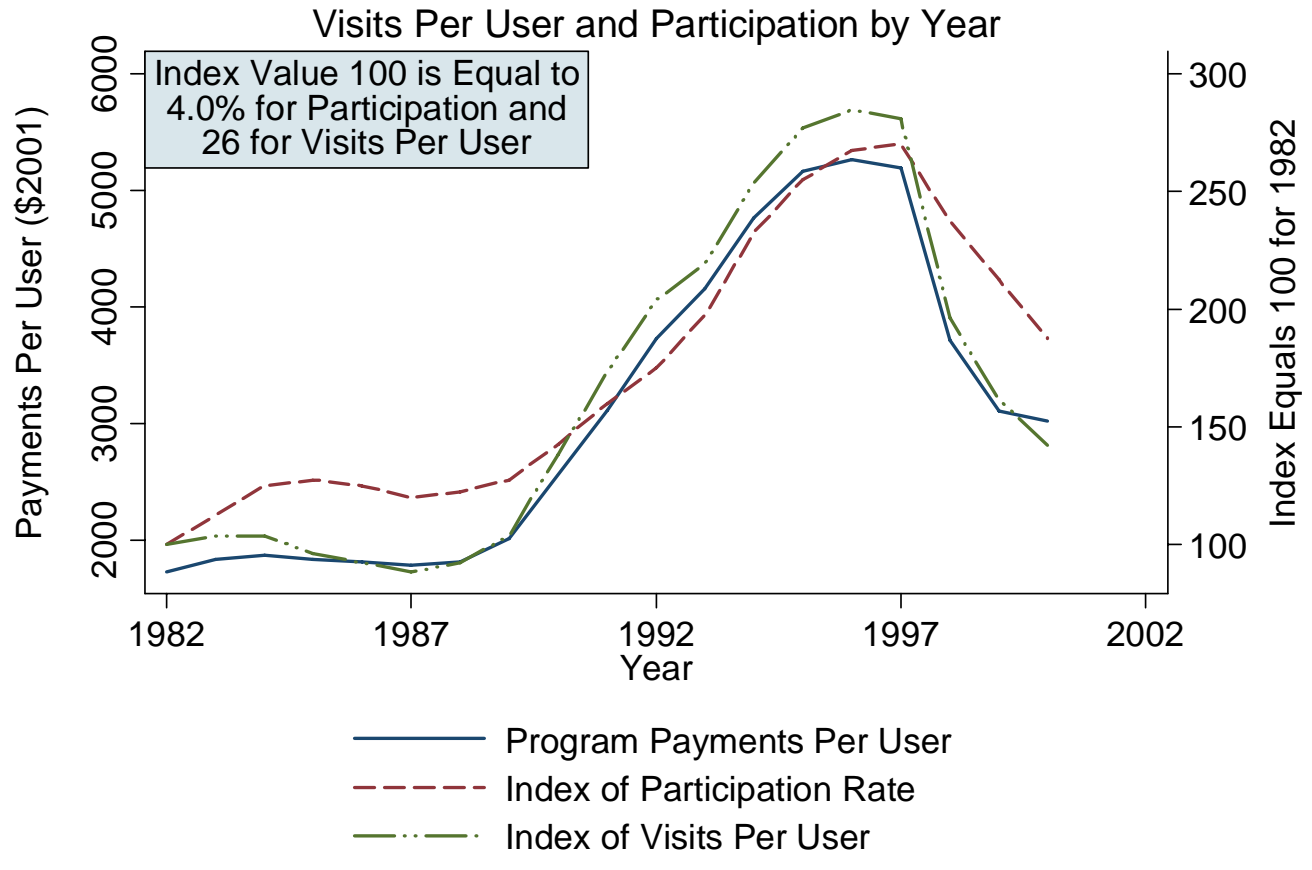


Figure 3. Elderly Shared Living Arrangements and Medicare Home Health Program Payments by Year

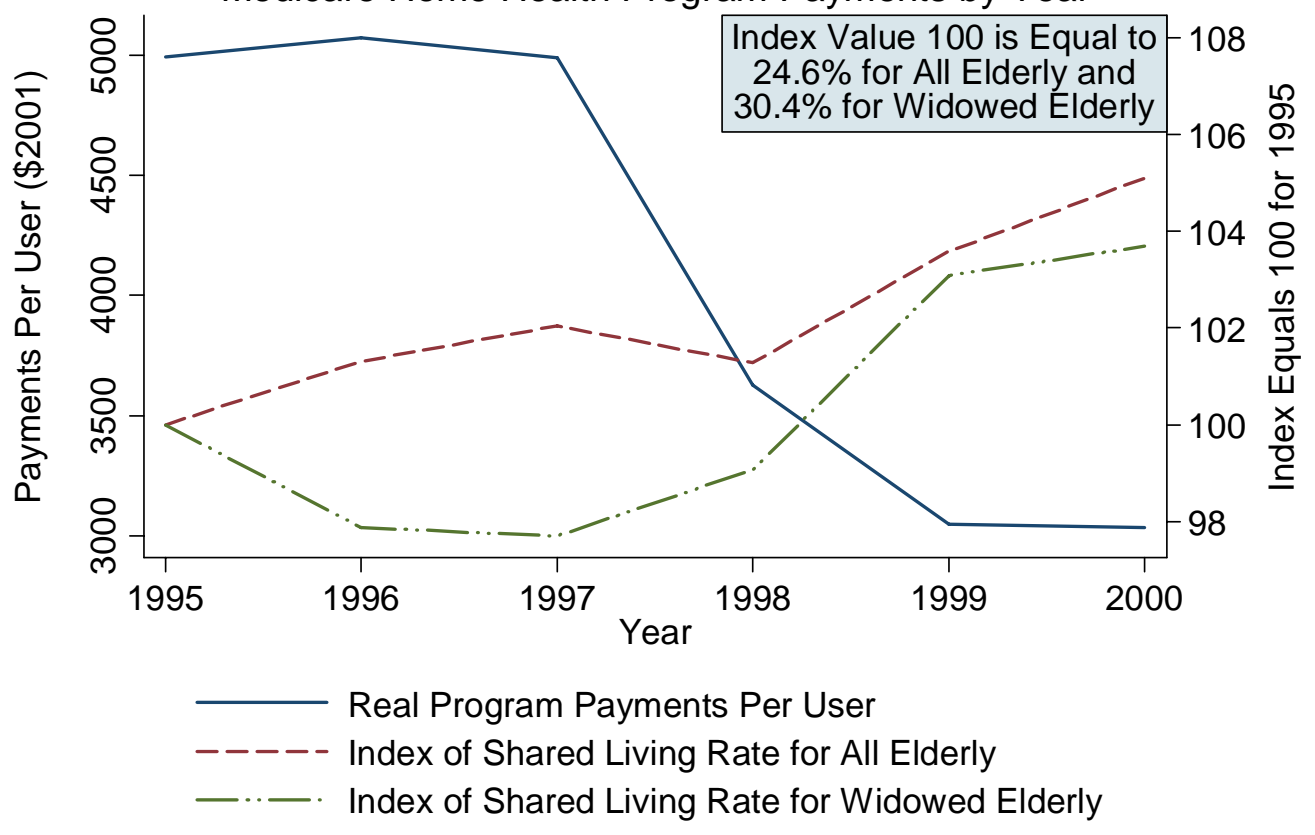


Figure 4. Elderly Shared Living Arrangements and Medicare Home Health Program Payments by Year

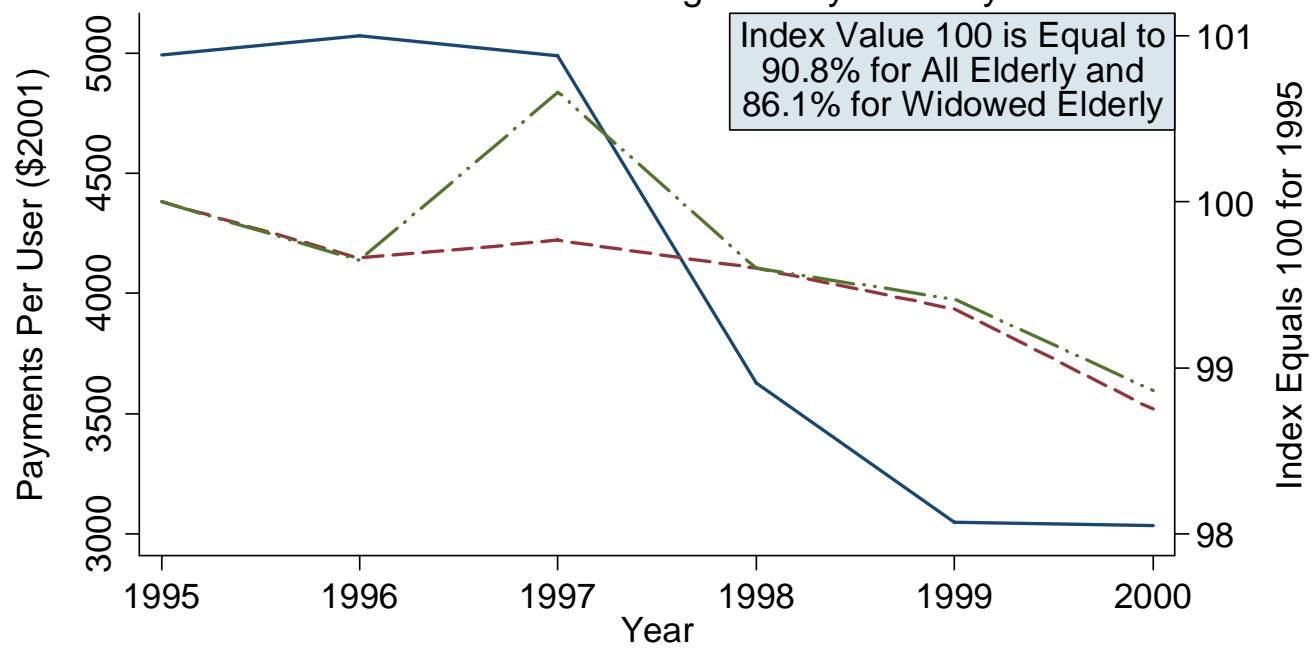

Real Program Payments Per User

- - - - Index of Household Headship Rate for All Elderly

-..- Index of Household Headship Rate for Widowed Elderly 
Figure 5. Elderly Homeownership and

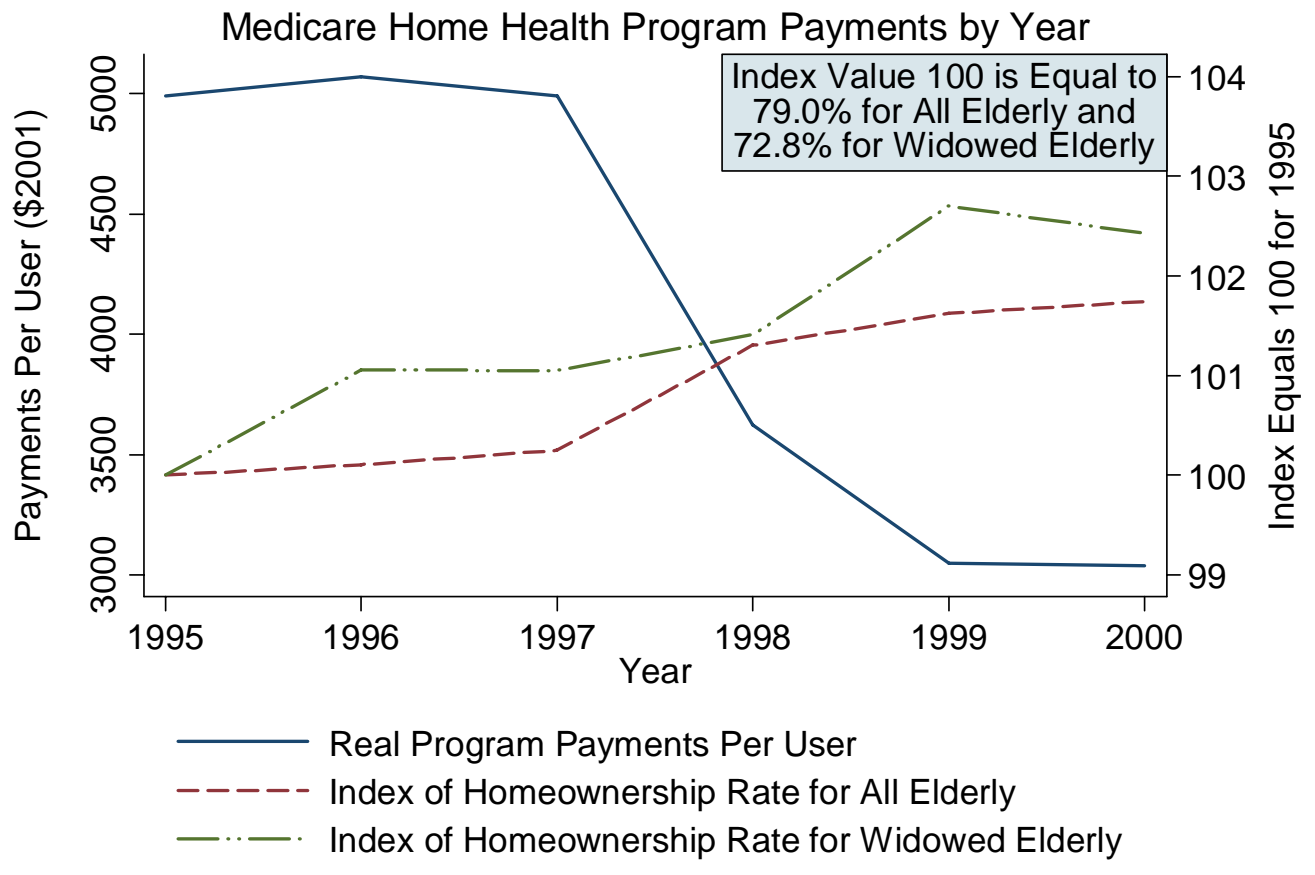


Figure 6. Medicaid Skilled Nursing Facility Program

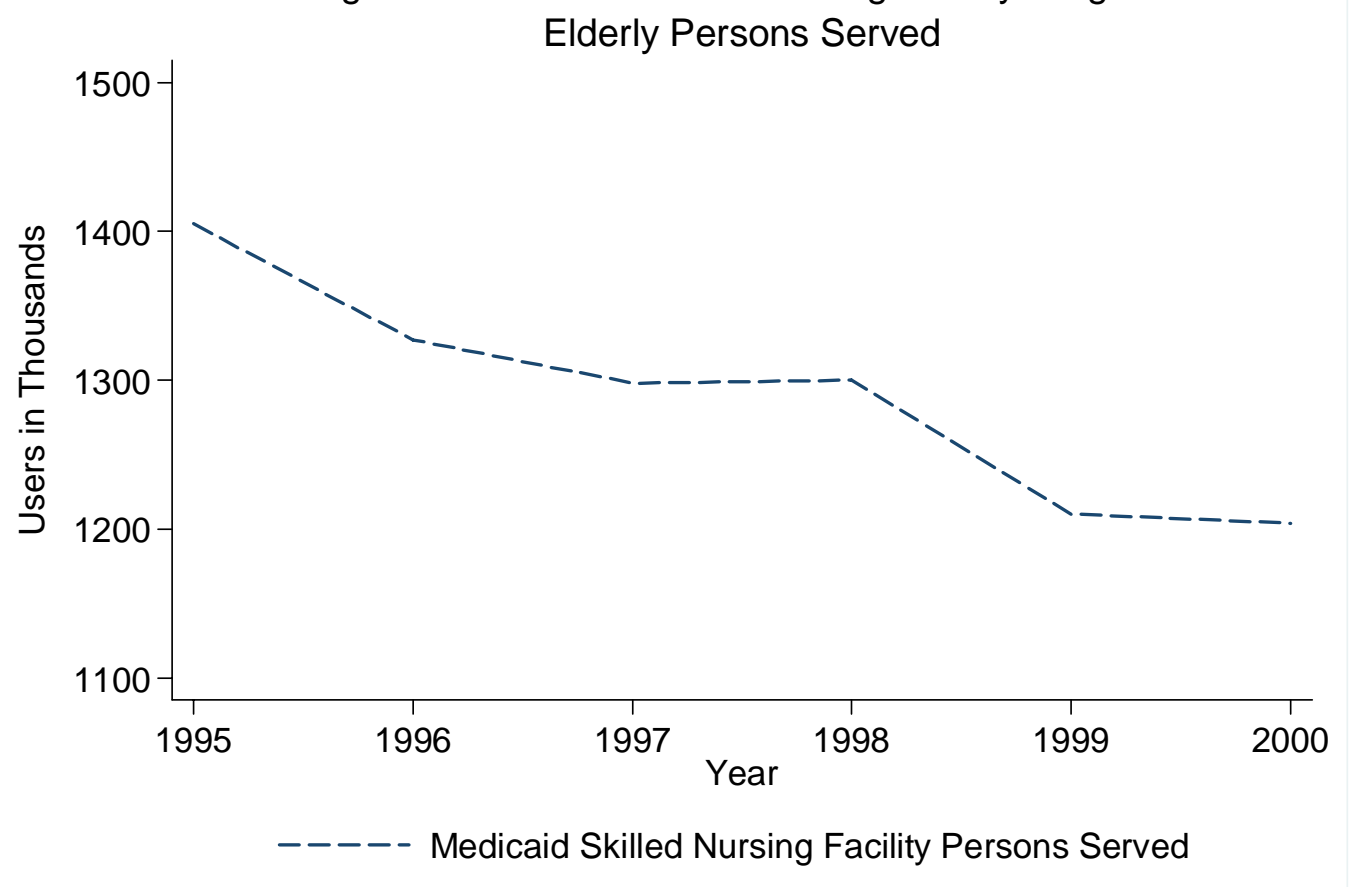




\section{RECENT WORKING PAPERS FROM THE}

\section{CENTER FOR RETIREMENT RESEARCH AT BOSTON COLLEGE}

The Impact of Changing Earnings Volatility on Retirement Wealth

Austin Nichols and Melissa M. Favreault, November 2008

The Housing Bubble and Retirement Security

Alicia H. Munnell and Mauricio Soto, with the assistance of Jean-Pierre Aubry, November 2008

How Much Do State and Economic and Other Characteristics Affect Retirement Behavior?

Alicia H. Munnell, Mauricio Soto, Robert K. Triest, and Natalia A. Zhivan, August 2008

Will People Be Healthy Enough to Work Longer?

Alicia H. Munnell, Mauricio Soto, and Alex Golub-Sass, August 2008

An Assessment of Life-Cycle Funds

Mauricio Soto, Robert K. Triest, Alex Golub-Sass, and Francesca Golub-Sass, May 2008

Participant Perceptions and Decision-Making Concerning Retirement Benefits

Colleen E. Medill, February 2008

A Micro-Level Analysis of Recent Increases in Labor Participation Among Older Workers

Kevin E. Cahill, Michael D. Giandrea, and Joseph F. Quinn, February 2008

The Trajectory of Wealth in Retirement

David A. Love, Michael G. Palumbo, and Paul A. Smith, February 2008

The Rising Age at Retirement in Industrial Countries

Gary Burtless, February 2008

The Implications of Career Lengths for Social Security

Melissa M. Favreault and C. Eugene Steuerle, February 2008

Do Out-of-Pocket Health Care Costs Delay Retirement?

Richard W. Johnson, Rudolph G. Penner, and Desmond Toohey, February 2008

All working papers are available on the Center for Retirement Research website

(http://www.bc.edu/crr) and can be requested by e-mail (crr@bc.edu) or phone (617-552-1762). 